\author{
В.Й. Климченко ${ }^{1}$, О.В. Бєлавін ${ }^{2}$, В.О. Тютюнник ${ }^{1}$, А.А. Лук’янчиков ${ }^{1}$ \\ ${ }^{1}$ Харківський начіональний університет Повітряних Сил ім. І. Кожедуба, Харків \\ ${ }^{2}$ Командування Повітряних Сил Збройних Сил України, Вінниия
}

\title{
АНАЛІЗ НОРМАТИВНО-ПРАВОВОЇ БАЗИ ЩОДО ПАСПОРТИЗАЦІЇ ПІДРОЗДІЛІВ РАДІОТЕХНІЧНИХ ВІЙСЬК
}

Проведено порівняльний аналіз світового досвіду визначення гранично допустимих рівнів електромагнітних полів в радіочастотному діапазоні для різних категорій населення з нормами та правилами щодо електромагнітної безпеки населення, які визначаються чинними в Украӥні нормативними документами. Виявлена низка протиріч в існуючій нормативно-правовій базі, які спричиняють викривлення в оцінюванні реально створюваної радіотехнічними підрозділами загрози населенню та довкіллю. Запропоновано науково обтрунтовані норми гранично допустимих рівнів електромагнітних полів, створюваних радіолокачійними засобами радіотехнічних військ, для населення і для осіб бойових обслуг, які зазнають професійного опромінювання.

Ключові слова: санітарні правила і норми, електромагнітна безпека, гранично допустимі рівні електромагнітних полів, оглядові радіолокаційні станиії.

\section{Вступ}

Постановка проблеми. Чинні на сьогодні в Україні нормативні документи щодо санітарних норм і правил захисту населення від впливу електромагнітних випромінювань розроблені в 90-х роках минулого століття на основі норм і правил, які діяли в СРСР. 3 урахуванням тих змін, які відбулись за три десятиріччя, означені документи не повною мірою відповідають сучасним умовам і потребують коригування в частині вимог до імпульсних джерел електромагнітного випромінювання.

Аналіз останніх досліджень і публікацій. Загальні вимоги щодо норм і правил захисту населення від впливу діяльності військових частин, установ, військово-навчальних закладів, підприємств та організацій Збройних Сил України визначаються в [1-2].

В цих документах зазначено, що навколо військових частин та оборонних об'єктів можуть створюватися зони з особливим режимом використання земель 3 метою забезпечення функціонування цих військових частин та захисту населення і довкілля від впливу наслідків їхньої діяльності.

Основним наслідком діяльності підрозділів радіотехнічних військ (РТВ) є потужне електромагнітне випромінювання, створюване радіолокаційними засобами контролю повітряного простору

Санітарні норми і правила захисту населення України від впливу електромагнітних випромінювань (ЕМВ) викладені в нормативних документах [3-5]. Аналіз існуючих норм, проведений в [6-7], та практика паспортизації радіотехнічних об’єктів сві- дчать про те, що вони певною мірою суперечать вимогам сучасності.

По-перше, в жодному з нормативних документів не визначено, які саме типи радіотехнічних об'єктів (РТО) підпадають під паспортизацію.

По-друге, існуючі нормативні документи не враховують тих змін, які відбулися за останні десятиріччя як в розвитку джерел електромагнітного випромінювання, так і в накопиченні досвіду їхнього впливу на живі організми.

По-третє, в існуючих документах не враховується світовий досвід розроблення норм і правил захисту населення від впливу електромагнітного випромінювання.

По-четверте, в процесі проведення робіт з паспортизації підрозділів радіотехнічних військ [8] 3'ясувалось, що в існуючих документах визначені вимоги лише до тих радіолокаційних засобів, які використовуються в різних сферах цивільної діяльності. Внаслідок цього розробники санітарних паспортів для підрозділів РТВ змушені користуватись вимогами до найближчих за функціями аналогів цивільного призначення.

Загальні підходи щодо визначення норм і правил захисту населення від впливу електромагнітних випромінювань в сучасних умовах наводяться в [9-10]. Але вони стосуються лише радіотехнічних об'єктів цивільного призначення. Щодо вимог до випромінювання такими специфічними джерелами, як радіолокаційні засоби, що перебувають на озброєнні радіотехнічних військ, то вони ніде не визначені. 
Отже, на сьогодні існує нагальна потреба в черговій корекції Державних санітарних норм і правил захисту населення від впливу електромагнітних випромінювань $з$ окремим визначенням гранично допустимих рівнів для радіолокаційних засобів спеціального призначення.

Метою цієї статті є розробка пропозицій щодо коригування існуючої нормативної бази в частині вимог до джерел електромагнітного випромінювання в радіочастотному діапазоні.

\section{Виклад основного матеріалу}

1. Аналіз світового досвіду визначення гранично допустимих рівнів електромагнітних полів для різних категорій населення.

Гігієнічні стандарти і норми в різних країнах традиційно розроблялися для двох категорій опро- мінювання - професійного, тобто опромінювання на робочих місцях, і непрофесійного - опромінювання населення, діяльність якого не пов'язана з використанням ЕМВ. Останнім часом формується ще одна категорія - професійне опромінювання особливого контингенту населення. До нього, перш за все, відносяться жінки в стані вагітності і особи, що не досягли 18 років. Для цих осіб в санітарних правилах i нормах деяких країн [11-13] встановлені достатньо жорсткі гранично допустимі рівні (ГДР) опромінювання. У ряді зарубіжних стандартів додатково встановлені особливі ГДР також для людей з імплантованими кардіостимуляторами.

В табл. 1 наведені [6;11-13] прийняті в різних країнах гранично допустимі рівні ЕМВ для населення та персоналу, що професійно зазнає впливу електромагнітних випромінювань.

Таблиця 1

Гранично допустимі рівні ЕМП в різних країнах

\begin{tabular}{|c|c|c|c|c|c|}
\hline \multirow{2}{*}{$\begin{array}{l}\text { Країна } \\
\text { (регіон) }\end{array}$} & \multirow{2}{*}{$\begin{array}{c}\text { ГДР для населен- } \\
\text { ня за цілодобового } \\
\text { опромінювання } \\
\text { мкВт/см² } \\
\text { (діапазон частот) }\end{array}$} & \multicolumn{2}{|c|}{$\begin{array}{c}\text { ГДР для населення за } \\
\text { часткового опромінювання } \\
\text { протягом доби }\end{array}$} & \multicolumn{2}{|c|}{$\begin{array}{c}\text { ГДР для персоналу за } \\
\text { часткового опромінювання } \\
\text { протягом доби }\end{array}$} \\
\hline & & $\begin{array}{c}\text { Час } \\
\text { опромінювання } \\
\text { протягом доби } \\
\end{array}$ & $\begin{array}{c}\text { ГДР мкВт/см² } \\
\text { (діапазон частот) }\end{array}$ & $\begin{array}{c}\text { Час } \\
\text { опромінювання }\end{array}$ & $\begin{array}{c}\text { ГДР мкВт/см² } \\
\text { (діапазон частот) }\end{array}$ \\
\hline $\begin{array}{l}\text { Україна до } \\
2017 \text { року }\end{array}$ & $\begin{array}{c}2,5 \\
(0,3-300) \Gamma Г ц\end{array}$ & - & - & $\begin{array}{l}\leq 8 \text { год } \\
\leq 2 \text { год } \\
\leq 20 \text { хв }\end{array}$ & $\begin{array}{c}25 \\
100 \\
1000\end{array}$ \\
\hline $\begin{array}{c}\text { Україна після } \\
20017 \text { року }\end{array}$ & 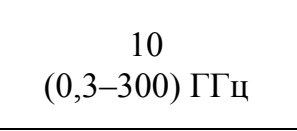 & - & - & $\begin{array}{l}\leq 8 \text { год } \\
\leq 2 \text { год } \\
\leq 20 \text { хв }\end{array}$ & $\begin{array}{c}25 \\
100 \\
1000 \\
\end{array}$ \\
\hline Угорщина & $\begin{array}{c}10 \\
(0,3-300) \Gamma \Gamma ц\end{array}$ & - & - & - & - \\
\hline $\begin{array}{c}\text { Країни } \\
\text { Скандинавії }\end{array}$ & $\begin{array}{c}100 \\
(0,3-300) \Gamma Г ц\end{array}$ & - & - & - & - \\
\hline Латвія & $\begin{array}{c}2 \\
(0,2-2) \Gamma \Gamma ц\end{array}$ & $\leq 30 \times \mathrm{xB}$ & $\begin{array}{c}450 \\
(900 \text { МГц }) ; \\
900 \\
(1800 \text { МГц }) ; \\
950 \\
(1900 \text { МГц }) \\
\end{array}$ & - & - \\
\hline $\begin{array}{c}\text { США, i } \\
\text { країни } \\
\text { Північної } \\
\text { Америки } \\
\text { ANSI/IEEE } \\
\end{array}$ & $\begin{array}{c}100 \\
(0,3-300) \text { ГГц }\end{array}$ & $\leq 30 \times \mathrm{xB}$ & $\begin{array}{c}600 \\
(900 \text { МГц); }\end{array}$ & $\leq 6 \times \mathrm{xB}$ & $\begin{array}{c}3000 \\
(900 \text { МГц) }\end{array}$ \\
\hline Росія & 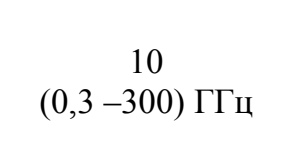 & - & - & $\begin{array}{l}\leq 8 \text { год } \\
\leq 2 \text { год } \\
\leq 20 \text { хв }\end{array}$ & $\begin{array}{c}25 \\
100 \\
1000\end{array}$ \\
\hline Білорусія & 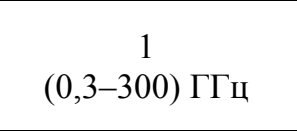 & - & - & $\begin{array}{l}\leq 8 \text { год } \\
\leq 2 \text { год } \\
\leq 20 \text { хв }\end{array}$ & $\begin{array}{c}10 \\
100 \\
1000\end{array}$ \\
\hline Казахстан & $\begin{array}{c}10 \\
(0,3-300) \Gamma \Gamma ц\end{array}$ & $\leq 20 \mathrm{xB}$ & $\begin{array}{c}500 \\
(0,3-300) \Gamma Г ц\end{array}$ & $\leq 20 \times \mathrm{xB}$ & $\begin{array}{c}1000 \\
(0,3-300) \Gamma Г ц\end{array}$ \\
\hline
\end{tabular}

Джерело: розроблено авторами за даними [6], с. 126; [11], табл. 3.3; [12], с. 4; [13], Дод. 3. 
Аналіз вмісту табл. 1 свідчить, що між гігієнічними стандартами та нормами щодо опромінювання електромагнітним полем (ЕМП), прийнятими в різних країнах, $є$ значні розходження. Так, гранично допустимі рівні ЕМП для населення в Білорусії та Латвії становлять одиниці мкВт/см², тоді як в країнах Північної Америки ця норма досягає 100 мкВт/см². В країнах Західної Європи ГДР ЕМП для

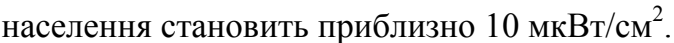

В Україні до 2017 року величина ГДР ЕМП для населення становила 2,5 мкВт/см², і тільки у 2017 році у зв'язку із впровадженням в країні систем мобільного зв'язку четвертого покоління до Державних санітарних норм і правил захисту населення від впливу електромагнітних випромінювань були внесені корективи [5] щодо доведення ГДР ЕМП до середньоєвропейського рівня, тобто до 10 мкВт/см². Але внесені корективи стосуються лише випадку непрофесійного опромінювання (опромінювання населення) джерелами неперервного випромінювання. Крім того, в жодному з чинних в Україні нормативних документів не визначено, які саме типи PTO є небезпечним для населення і підпадають під обов'язкову паспортизацію. В нормативних документах деяких іноземних країн [11-12] визначено, що під паспортизацію не підпадають ті РТО, які мають антени 3 коефіцієнтом направленої дії не більше 5 і максимальну потужність, що не перевищує наступних значень:

- 40 Вт - в діапазоні частот 30 кГц - 3 МГц;

- 20 Вт - в діапазоні частот 3 МГц- 30 МГц;

-2 Вт - в діапазоні частот 30 МГц - 300 ГГц.

Такі обмеження доцільно було б ввести і в Державні санітарні норми і правила захисту населення України від впливу електромагнітного випромінювання.
2. Аналіз вимог щодо гранично допустимих рівнів електромагнітних полів, що утворюються радіолокаційними засобами радіотехнічних військ, для цивільного населення України.

Рівень електромагнітного поля, що утворюється радіолокаційними засобами радіотехнічних військ в межах населених пунктів значною мірою залежить від взаємного розташування позицій підрозділів та житлових забудов.

Основні вимоги щодо розміщення засобів електромагнітного випромінювання відносно населених пунктів визначені в [3]. Там же визначені також загальні вимоги щодо гранично допустимих рівнів електромагнітних полів, що утворюються радіотехнічними засобами для населення.

3 метою захисту населення від дії електромагнітних полів, створених передавальними радіотехнічними засобами, встановлюються санітарно-захисні зони і зони обмеженої забудови, які повинні забезпечувати на житловій території, в житлових приміщеннях та інших місцях перебування людей рівні електромагнітного поля, що не перевищують гранично допустимі рівні, які наведені в табл. 2 .

Розміри санітарно-захисних зон і зон обмеження забудови радіотехнічних об'єктів визначаються на стадії проектування розрахунковими методами, затвердженими або погодженими МО3 України, для кожного конкретного об'єкта в залежності від його складу і призначення, потужності, робочої частоти, типу і висоти установки антен над рівнем землі, рельєфу місцевості, поверховості і планувального рішення існуючої забудови.

Результати розрахунку після введення в експлуатацію радіопередавального об'єкта перевіряються інструментальними вимірами.

Таблиця 2

Гранично допустимі рівні електромагнітних полів,

що створюються радіолокаційними засобами з імпульсним випромінюванням

\begin{tabular}{|c|c|c|c|c|c|c|c|}
\hline \multirow[b]{2}{*}{$\begin{array}{c}\text { Призначення } \\
\text { РЛС }\end{array}$} & \multirow[b]{2}{*}{$\begin{array}{c}\text { Номер } \\
\text { діапазону }\end{array}$} & \multirow[b]{2}{*}{$\begin{array}{c}\text { Довжина } \\
\text { хвилі, } \\
\text { см }\end{array}$} & \multicolumn{3}{|c|}{$\begin{array}{l}\text { Режим } \\
\text { роботи }\end{array}$} & \multirow{2}{*}{$\begin{array}{c}\text { Відношення } \\
\text { тривалості } \\
\text { опромінювання } \\
\text { до загального } \\
\text { часу на добу }\end{array}$} & \multirow[b]{2}{*}{$\begin{array}{c}\text { ГДР, } \\
\text { мкВТ/см² }\end{array}$} \\
\hline & & & $\begin{array}{c}\text { Швидкість } \\
\text { обертання } \\
\text { антени, } \\
\text { об/хв } \\
\end{array}$ & $\begin{array}{c}\text { Період } \\
\text { огляду, } \\
\text { с }\end{array}$ & \begin{tabular}{|c|} 
Час \\
опромінювання 3 \\
однопорядковою \\
інтенсивністю \\
\end{tabular} & & \\
\hline 1 & 2 & 3 & 4 & 5 & 6 & 7 & 8 \\
\hline \multirow{4}{*}{$\begin{array}{c}\text { Метеорологічні } \\
\text { РЛС та інші їм } \\
\text { подібні за } \\
\text { режимом } \\
\text { роботи }\end{array}$} & \multirow{2}{*}{11} & \multirow{2}{*}{$0,8 \pm 0,12$} & $\leq 6$ & $\geq 10$ & $\begin{array}{c}\leq 0,001 \text { періоду } \\
\text { огляду }\end{array}$ & 0,5 & 140 \\
\hline & & & 0 & - & $\begin{array}{c}\leq 12 \text { годин } \\
\text { на добу }\end{array}$ & 1 & 10 \\
\hline & \multirow{2}{*}{10} & \multirow{2}{*}{$3 \pm 0,6$} & $\leq 6$ & $\geq 10$ & $\begin{array}{c}\leq 0,004 \text { періоду } \\
\text { огляду }\end{array}$ & 0,5 & 60 \\
\hline & & & 0 & - & $\begin{array}{c}\leq 12 \text { годин } \\
\text { на добу }\end{array}$ & 1 & 10 \\
\hline
\end{tabular}


Закінчення табл. 2

\begin{tabular}{|c|c|c|c|c|c|c|c|}
\hline \multirow{5}{*}{1} & & & & & & \\
\hline & 2 & 3 & 4 & 5 & 6 & 7 & 8 \\
\hline & \multirow{3}{*}{9} & \multirow{2}{*}{$10 \pm 1,5$} & $\leq 6$ & $\geq 10$ & $\begin{array}{c}\leq 0,008 \text { періоду } \\
\text { огляду }\end{array}$ & 0,5 & 40 \\
\hline & & & 0 & - & $\begin{array}{c}\leq 12 \text { годин } \\
\text { на добу }\end{array}$ & 1 & 20 \\
\hline & & $17 \pm 2,55$ & 0 & - & $\begin{array}{c}\leq 12 \text { годин } \\
\text { на добу }\end{array}$ & 0,5 & 24 \\
\hline \multirow{3}{*}{$\begin{array}{c}\text { Оглядові РЛС } \\
\text { цивільної авіації } \\
\text { та інші їм подібні } \\
\text { за режимом } \\
\text { роботи }\end{array}$} & \multirow{3}{*}{9} & $10 \pm 2$ & $\leq 15$ & $\geq 4$ & \begin{tabular}{|c|}
$\leq 0,0063$ пері- \\
оду огляду
\end{tabular} & 1 & 15 \\
\hline & & $23 \pm 3,45$ & $\leq 15$ & $\geq 4$ & $\begin{array}{c}\leq 0,004 \text { періоду } \\
\text { огляду }\end{array}$ & 1 & 20 \\
\hline & & $35 \pm 5,25$ & $\leq 15$ & $\geq 4$ & $\begin{array}{c}\leq 0,011 \text { періоду } \\
\text { огляду }\end{array}$ & 1 & 25 \\
\hline \multirow{2}{*}{$\begin{array}{c}\text { Берегові, суднові } \\
\text { оглядові РЛС та } \\
\text { інші їм подібні за } \\
\text { режимом роботи }\end{array}$} & \multirow{2}{*}{9} & \multirow{2}{*}{$10 \pm 1,5$} & \multirow{2}{*}{$\leq 25$} & \multirow{2}{*}{$\geq 2,4$} & $\begin{array}{c}\leq 12 \text { годин } \\
\text { на добу }\end{array}$ & 1 & 15 \\
\hline & & & & & $\begin{array}{c}\leq 6 \text { годин } \\
\text { на добу }\end{array}$ & 1 & 20 \\
\hline
\end{tabular}

Джерело: розроблено авторами за даними [3], Дод. 22.

Санітарно-захисна зона для передавальних радіостанцій, обладнаних антенами ненаправленої дії, для телецентрів і телевізійних ретрансляторів, а також для радіолокаційних станцій кругового огляду встановлюється по колу.

Для передавальних радіостанцій, обладнаних антенами направленої дії, а також для радіолокаційних станцій, антени яких сканують у визначеному секторі або фіксовані в заданому напрямку, санітарно-захисна зона встановлюється в напрямку діаграми випромінювання електромагнітних хвиль. У цьому випадку повинні враховуватись бокові і задні пелюстки діаграми випромінювання антен.

Для передавальних радіостанцій, телецентрів, телевізійних ретрансляторів, радіолокаційних станцій, антени яких випромінюють електромагнітні хвилі під кутом до горизонту і в результаті цього величина електромагнітного поля змінюється в за- лежності від висоти місця його визначення над рівнем землі, зони обмеженої забудови встановлюються диференційно по вертикалі для таких висот (в метрах): 3, 6, 9, 12, 15 і т.д.

Земельні ділянки, що входять в санітарнозахисну зону, не вилучаються у землекористувачів і можуть використовуватись як сільськогосподарські угіддя, а також для розміщення на них виробничих споруд, що належать радіотехнічному об'єкту або іншим відомствам, 3 дотриманням вимог діючих санітарних норм і правил.

Якщо санітарно-захисна зона перевищує технічну зону, то вона відгороджується попереджувальними знаками “Заборонна зона". В [4] (табл. 3) в основному повторюються вимоги щодо гранично допустимих рівнів ЕМП, які викладені в [3], але $\epsilon$ певні відмінності. Значення ГДР для деяких режимів роботи РЛС в наказі № 239 чомусь не визначені.

Таблиця 3

Гранично допустимі рівні електромагнітних полів, що створюються радіолокаційними засобами з імпульсним випромінюванням

\begin{tabular}{|c|c|c|c|c|c|c|c|}
\hline \multirow[b]{2}{*}{$\begin{array}{c}\text { Призначення } \\
\text { РЛС }\end{array}$} & \multirow[b]{2}{*}{$\begin{array}{c}\text { Номер } \\
\text { діапазону }\end{array}$} & \multirow[b]{2}{*}{$\begin{array}{c}\text { Довжина } \\
\text { хвилі, } \\
\text { см }\end{array}$} & \multicolumn{3}{|c|}{ Режим роботи } & \multirow{2}{*}{$\begin{array}{c}\text { Відношення } \\
\text { тривалості } \\
\text { опромінювання до } \\
\text { загального часу на } \\
\text { добу } \\
\end{array}$} & \multirow[b]{2}{*}{$\begin{array}{c}\text { ГДР, } \\
\text { мКВт/см² }\end{array}$} \\
\hline & & & \begin{tabular}{|c|} 
Швидкість \\
обертання \\
антени, \\
об/хв \\
\end{tabular} & $\begin{array}{c}\text { Період } \\
\text { огляду, } \\
\text { с }\end{array}$ & $\begin{array}{c}\text { Час } \\
\text { опромінювання } 3 \\
\text { однопорядковою } \\
\text { інтенсивністю }\end{array}$ & & \\
\hline 1 & 2 & 3 & 4 & 5 & 6 & 7 & 8 \\
\hline \multirow{4}{*}{$\begin{array}{c}\text { Метеорологічні } \\
\text { РЛС та інші їм } \\
\text { подібні за } \\
\text { режимом } \\
\text { роботи }\end{array}$} & \multirow{2}{*}{11} & \multirow{2}{*}{$0,8 \pm 0,12$} & $\leq 6$ & $\geq 10$ & $\begin{array}{c}\leq 0,001 \text { періоду } \\
\text { огляду }\end{array}$ & 0,5 & 140 \\
\hline & & & 0 & $\begin{array}{c}\text { Без } \\
\text { огляду }\end{array}$ & $\begin{array}{l}\leq 12 \text { годин } \\
\text { на добу }\end{array}$ & 1 & 10 \\
\hline & \multirow{2}{*}{10} & \multirow{2}{*}{$3 \pm 0,6$} & $\leq 6$ & $\geq 10$ & $\begin{array}{c}\leq 0,004 \text { періоду } \\
\text { огляду }\end{array}$ & 0,5 & 60 \\
\hline & & & 0 & $\begin{array}{c}\text { Без } \\
\text { огляду }\end{array}$ & $\begin{array}{l}\leq 12 \text { годин } \\
\text { на добу }\end{array}$ & 1 & - \\
\hline
\end{tabular}


Закінчення табл. 3

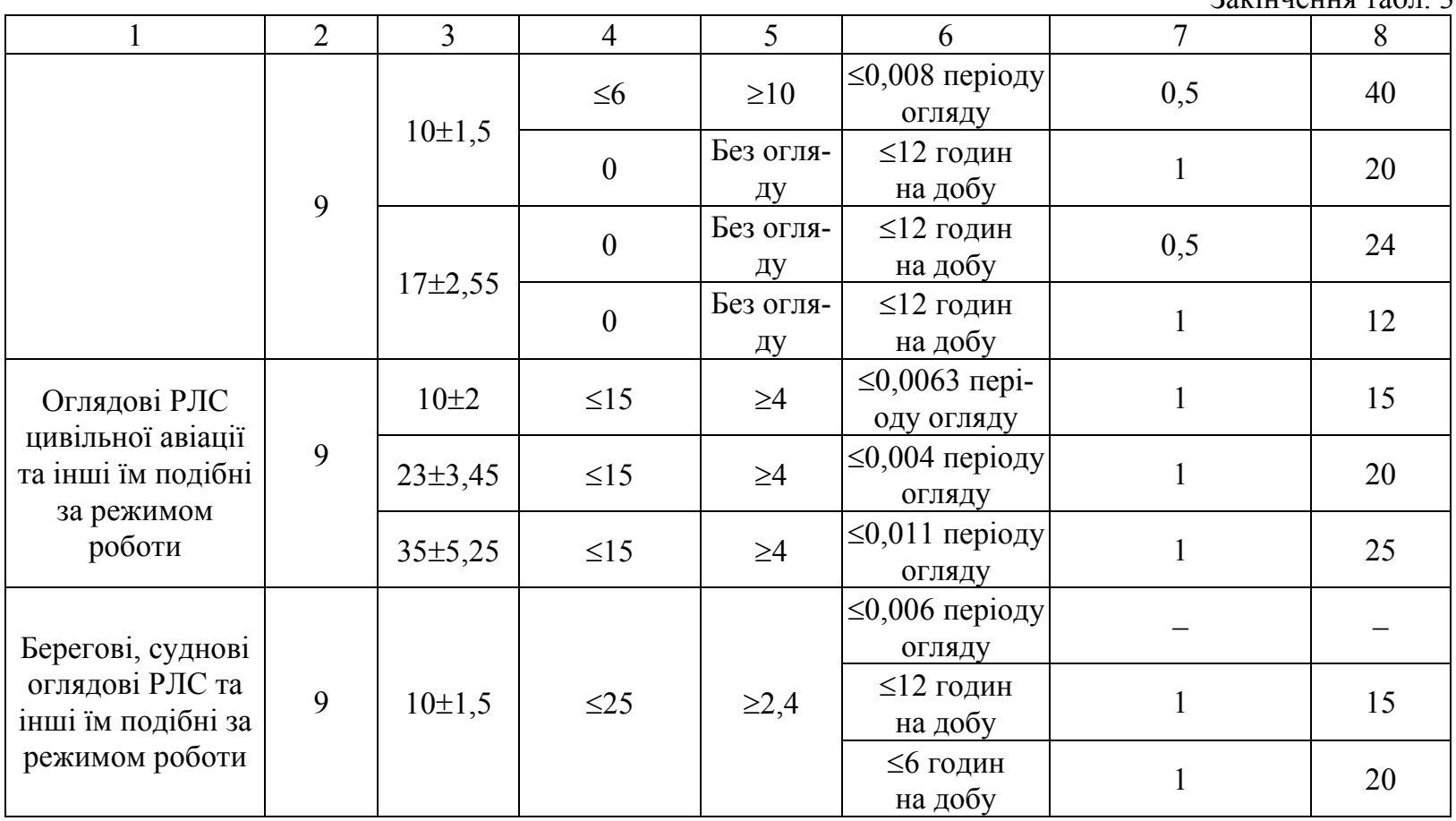

Джерело: розроблено авторами за даними [4], табл. 1.3.

Порівняння вмісту табл. 2, табл. 3 свідчить, що ні в першому ні в другому документі вимоги щодо ГДР ЕМП, створюваного такими РЛС, як оглядові РЛС РТВ, не визначені. За режимами роботи та діапазоном частот існуючі на озброєнні РТВ радіолокаційні засоби частково можна віднести до зазначеного в [3-4] класу "Метеорологічні РЛС та інші імм подібні за режимом роботи”, більшою мірою до класу “Оглядові РЛС цивільної авіації та інші їм подібні за режимом роботи" і частково до класу “Берегові, суднові оглядові РЛС та інші їм подібні за режимом роботи". Але режими роботи і параметри РЛС РТВ відрізняються від тих засобів радіолокації, для яких визначені ГДР ЕМП в [3-4]. Крім того, в документах [3-4] наведені гранично допустимі рівні електромагнітного поля для цивільного населення лише для РЛС, які працюють в 9 (300 МГц - 3 ГГц), 10 (3 ГГц - 30 ГГц) та 11 (30 ГГц - 300 ГГц) частотних діапазонах, тоді як РЛС РТВ працюють, крім дев'ятого та десятого, ще і в восьмому (30 МГц 300 МГц) діапазоні.

В жодному із наведених вище нормативних документів відсутнє пряме пояснення, за яких умов визначено гранично допустимі рівні електромагнітних полів, що створюються радіолокаційними засобами з імпульсним випромінюванням. Ці умови можна визначити лише опосередковано. В пункті 1.3.1 [4] вказано, що гранично допустимі рівні напруженості електричного поля (електричної складової ЕМП) визначаються середньоквадратичним (ефективним) значенням, а гранично допустимі рівні густини потоку потужності визначаються як середні значення за час роботи джерела випромінювання.

Отже, для оглядових РЛС, які працюють в імпульсному режимі, усереднення має здійснюватися не тільки за період повторення зондувальних імпульсів, через використання середньої потужності передавача, а й за період огляду простору з урахуванням направлених властивостей антени (ширини променю в горизонтальній площині, коефіцієнта підсилення антени та рівня бічних пелюсток ДНА). Методика такого усереднення наведена в [15].

Але в табл. 2, табл. 3 наводяться допустимі рівні густини потоку потужності за умови опромінювання однопорядковою інтенсивністю (стовпчик 6: Час опромінювання з однопорядковою інтенсивністю), який становить соті частки від періоду огляду. Якщо ж об'єкт перебуває постійно в зоні головного променю (рядок “Без огляду"), то допустимі рівні густини потоку потужності зменшуються на порядок. Виходячи зі сказаного, в означених документах йдеться про допустимі рівні густини потоку потужності, створюваної головним променем антени.

В п. 1.3.3 [4] зазначено, що гранично допустимий рівень ЕМП, що створюють інші типи станцій, які не ввійшли до табл. 2, в тому числі радіолокаційні засоби, що працюють в імпульсному режимі випромінювання встановлюється $6 \mathrm{~B} / \mathrm{м}$ в 8 діапазоні

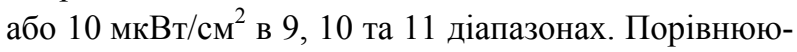
чи ці цифри із гранично допустимими рівнями ЕМП, зазначеними в [3-4], можна зробити висно-

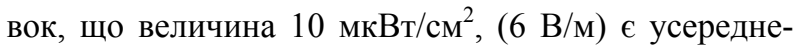
ним середньодобовим значенням граничного рівня ЕМП, тобто це та межа, яку не можна перевищувати 
при постійному опроміненні місцевості неперервним випромінюванням.

Існує також межа і для ГДР короткочасного випромінювання, яка в [3-4] не визначена, а випливає опосередковано із вимог [14], де визначені ГДР ЕМП для обслуговуючого радіотехнічні об'єкти персоналу і вказано, що максимальний рівень ЕМП навіть при короткочасній дії не повинен перевищувати 1000 мкВт/см². В деяких країнах (див. табл. 1) означений рівень становить 3000 мкВт/см².

Отже, якщо взяти за основу гранично допустимий рівень неперервного випромінювання

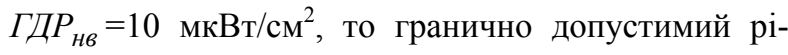
вень ЕМП, створюваного головним променем оглядової РЛС РТВ ГДР женням означеної цифри на коефіцієнт усереднення $k_{y c}$, визначений в [15]. Крім того, необхідно враховувати особливість вимірювання густини потоку потужності НВЧ коливань. А вона полягає в тому, що всі вимірювачі потужності в цьому діапазоні мають дуже низьку точність вимірювання.

Відносна похибка сягає (30-50)\%. Це означає, що істинне значення величини може бути вдвічі більше, ніж виміряне.

3 урахуванням цього гранично допустимий рівень ЕМП, створюваного головним променем оглядової РЛС РТВ, може бути визначений, як:

$$
\Gamma Д P_{\text {гn }}=0,5 \cdot k_{y c} \cdot Г Д P_{н в} \cdot
$$

Якщо отримане значення не перевищує половину гранично допустимого рівня короткочасного опромінювання $0,5 \cdot Г Д P_{\kappa о}=500 \mathrm{M \kappa BT} / \mathrm{cm}^{2}$ (значення $0,5 \cdot Г Д Р_{\kappa о}$ взяте знову ж таки з міркувань низької точності вимірювальних приладів), то воно залишається дійсним, як ГДР гп для даного типу РЛС.
В разі, коли ГДР 2 гn $\geq 0,5 \cdot Г Д P_{к о}$, дійсним для даного типу РЛС приймається значення 0,5 ГДР ко . Отже:

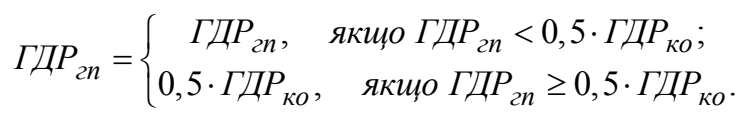

Визначені за співвідношеннями (1-2) значення $Г Д P_{2 n}$ для радіолокаційних засобів, що перебувають на озброєнні РТВ, наведені в табл. 4.

Аналіз вмісту табл. 4 доводить, що розрахункові значення гранично допустимих рівнів ЕМП, створюваного головним променем ДСА радіолокаційних засобів, які перебувають на озброєнні РТВ, суттєво перевищують аналогічні значення для цивільних радіолокаційних засобів з імпульсним випромінюванням, визначені в [3-4] (див. табл. 2, 3). Цьому може бути кілька причин.

По-перше, наказом МО3 від 13.03.2017 № 266 були некоректно внесені зміни до Державних санітарних норм і правил захисту населення від впливу електромагнітних випромінювань (зміни до наказу MO3 від 01.08.1996 № 239). Зміни торкнулись лише гранично допустимого рівня неперервного випромі-

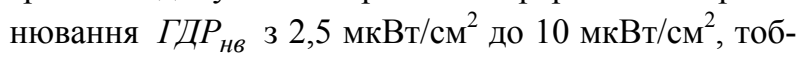
то підвищення відбулось вчетверо, а пропорційне збільшення гранично допустимих рівнів ЕМП для цивільних радіолокаційних засобів 3 імпульсним випромінюванням проведене не було.

По-друге, параметри цивільних радіолокаційних засобів і радіолокаційних засобів спеціального призначення суттєво відрізняються.

По-третє, первісно в наказі МОЗ від 01.08.1996 № 239 норми щодо ГДР ЕМП для імпульсних радіолокаторів були занижені.

Гранично допустимі рівні густини потоку потужності, створюваного головним променем ДНА РЛС

\begin{tabular}{|c|c|c|c|c|c|c|c|c|c|c|c|}
\hline \multirow[b]{2}{*}{ Параметр } & \multicolumn{11}{|c|}{ Тип РЛС } \\
\hline & $\begin{array}{l}0 \\
\infty \\
\infty\end{array}$ & 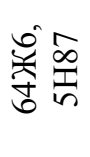 & $\hat{n}$ & 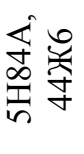 & 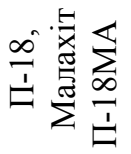 & $\stackrel{m}{\Xi}$ & 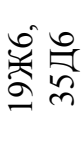 & 高党 & $\frac{n}{\frac{n}{n}}$ & $\begin{array}{l}0 \\
\frac{1}{2} \\
\text { 尚 }\end{array}$ & $\frac{n}{\frac{1}{n}}$ \\
\hline$k_{y c}$ & 187 & 413 & 209 & 46 & 25 & 40 & 174 & 53 & 1462 & 1445 & 1915 \\
\hline $\begin{array}{c}\Gamma Д P_{2 n}, \\
м \kappa B m / c M^{2}\end{array}$ & 500 & 500 & 500 & 230 & 125 & 200 & 500 & 265 & 500 & 500 & 500 \\
\hline
\end{tabular}

Джерело: розроблено авторами.

Таким чином, на сьогодні існує нагальна потреба чергової корекції Державних санітарних норм i правил захисту населення від впливу електромагнітних випромінювань з окремим визначенням ГДР для радіолокаційних засобів спеціального призначення.
3. Гранично допустимі рівні електромагнітних випромінювань для бойових обслуг на позиціях радіотехнічних підрозділів.

Нормативного документу, який би визначав гранично допустимі рівні електромагнітних випро- 
мінювань для осіб бойових обслуг на позиціях радіотехнічних підрозділів, не існує. Тому за основу необхідно приймати обмеження, які встановлюються гігієнічними стандартами і нормами для осіб, які зазнають професійного опромінювання, тобто опромінювання на робочих місцях. В Україні такі норми визначені наказом Міністерства охорони здоров'я України від 18.12.2002 № 476, яким затверджені Державні санітарні норми та правила при роботі 3 джерелами електромагнітних полів [14]. Значення ГДР густини потоку потужності на робочих місцях залежно від тривалості дії ЕМП наведені в табл. 5.

Таблиця 5

Гранично допустимі рівні густини потоку потужності

на робочих місцях залежно від тривалості опромінювання

\begin{tabular}{|c|c|c|c|c|c|c|c|c|c|c|c|}
\hline $\begin{array}{c}\text { Час } \\
\text { перебування } \\
\text { персоналу, } \\
\text { год }\end{array}$ & 8 & 7 & 6 & 5 & 4 & 3 & 2 & 1 & 0,5 & 0,25 & 0,2 \\
\hline $\begin{array}{c}\text { ГР ЕМП, } \\
\text { мкВт/см }\end{array}$ & 25 & 29 & 33 & 40 & 50 & 67 & 100 & 200 & 400 & 800 & 1000 \\
\hline
\end{tabular}

Джерело: розроблено авторами за даними [14], табл. 5.

При тривалості опромінювання менше 0,2 год. подальше підвищення ГДР ЕМП не допускається.

Якщо перерахувати зазначені в табл. 5 короткочасні гранично допустимі рівні в середнє цілодобове значення, то отримаємо середній рівень за добу 8 мкВт/см². Це значення приблизно втричі перевищувало встановлений на той час Державними санітарними нормами і правилами захисту населення від впливу електромагнітного випромінювання [4] граничний допустимий рівень неперервного опромінювання населення в 2,5 мкВт/см².

32017 року граничний допустимий рівень неперервного опромінювання населення було підвищено [5] до 10 мкВт/см², і тепер допустимий рівень професійного опромінювання виявляється нижчим за допустимий рівень непрофесійного опромінювання. Причина криється в тому, що зміни [5] стосувались тільки Державних санітарних норм і правил захисту населення від впливу електромагнітного випромінювання щодо норм неперервного опромінювання населення, а Державні санітарні норми та правила при роботі з джерелами електромагнітних полів [14] пропорційній корекції піддані не були. Якби така корекція відбулась, то зазначені в табл. 5 рівні професійного опромінювання були б збільшені вчетверо і співвідношення між допустимим рівнем неперервного опромінювання населення і середньодобовим рівнем професійного опромінювання було б, як і раніше, 1:3. Приблизно такі рівні і таке співвідношення між ними є характерним для нормативних документів країн Свропи і Північної Америки.

Отже, Державні санітарні норми та правила при роботі з джерелами електромагнітних полів необхідно також піддати корекції з урахуванням граничного допустимого рівня неперервного опромінювання населення 10 мкВт/см². При цьому граничним рівнем короткочасного опромінювання залишити рівень у 1000 мкВт/см². 3 урахуванням означених норм пропонуються гранично допустимі рівні густини потоку потужності на робочих місцях залежно від тривалості опромінювання, які наведені в табл. 6.

Таблиця 6

Пропозиції щодо гранично допустимих рівнів густини потоку потужності на робочих місцях залежно від тривалості опромінювання

\begin{tabular}{|c|c|c|c|c|c|c|c|c|c|}
\hline $\begin{array}{c}\text { Час перебування } \\
\text { персоналу, год }\end{array}$ & 8 & 7 & 6 & 5 & 4 & 3 & 2 & 1 & $\leq 0,8$ \\
\hline $\begin{array}{c}\text { ГДР ЕМП, } \\
\text { мкВт/см }\end{array}$ & 100 & 116 & 132 & 160 & 200 & 268 & 400 & 800 & 1000 \\
\hline
\end{tabular}

Джерело: розроблено авторами.

При цьому граничним рівнем короткочасного опромінювання залишити рівень у 1000 мкВт/см², перевищення якого є неприпустимим.

\section{Висновки}

Аналіз існуючих нормативних документів щодо санітарних норм і правил захисту населення від впливу електромагнітних випромінювань, що діють на сьогодні в Україні, виявив низку суттєвих недоліків, які потребують негайного усунення:

1. Не визначені параметри тих РТО, які становлять небезпеку для населення і обслуговуючого персоналу і які мають підпадати під обов'язкову паспортизацію. Пропонується визнати такими ті РТО, які мають антени 3 коефіцієнтом направленої дії більше 5 і максимальну потужність не менше, ніж: 
- 40 Вт - в діапазоні частот 30 кГц - 3 МГц;

- 20 Вт - в діапазоні частот 3 МГц- 30 МГц;

-2 Вт - в діапазоні частот 30 МГц - 300 ГГц.

2. В нормативних документах вимоги щодо ГДР ЕМП, створюваного такими РЛС, як РЛС РТВ, не визначені. За діапазоном частот, потужністю, режимами роботи та за тактико-технічними характеристиками існуючі на озброєнні РТВ радіолокаційні засоби суттєво відрізняються від зазначених в нормативних документах класів радіолокаційних засобів. Тому є нагальна необхідність у визначенні гранично допустимих рівнів ЕМВ для такого класу радіолокаційних засобів, як РЛС РТВ. І ці рівні мають визначатися не для класу в цілому, а для кожного типу РЛС окремо, оскільки ГДР суттєво залежать від ТТХ РЛС. Обгрунтовані вимоги щодо гранично допустимих рівнів густини потоку потужності, створюваного головним променем ДНА РЛС РТВ наведені в табл. 4.

3. Відсутні нормативні документи, які б визначали гранично допустимі рівні електромагнітних випромінювань для осіб бойових обслуг на позиціях радіотехнічних підрозділів. За основу можна прийняти обмеження, які встановлюються “Державними санітарними нормами та правилами при роботі 3 джерелами електромагнітних полів”. Але їх необхідно піддати корекції з урахуванням граничного допустимого рівня неперервного опромінювання населення 10 мкВт/см². Означена корекція наведена в табл. 5.

\section{Список літератури}

1. Закон України “Про використання земель оборони № 1345 від 27.11.2003” [Електронний ресурс]. - Режим доступу: https://zakon.rada.gov.ua/laws/show/1345-15.

2. Закон України "Про забезпечення санітарного та епідемічного благополуччя населення № 4004 від 24.02.1994" [Електронний ресурс]. - Режим доступу: https://zakon.rada.gov.ua/laws/show/4004-12.

3. Наказ Міністерства охорони здоров'я України “Про затвердження Державних санітарних правил планування та забудови населених пунктів № 173 від 19.06.1996” [Електронний ресурс]. - Режим доступу: https://zakon.rada.gov.ua/laws/show/z0379-96.

4. Наказ Міністерства охорони здоров’я України “Державні санітарні норми і правила захисту населення від впливу електромагнітного випромінювання № 239 від 01.08.1996” [Електронний ресурс]. - Режим доступу: https://zakon.rada.gov.ua/laws/show/z0488-96.

5. Наказ Міністерства охорони здоров'я України “Про затвердження Змін до Державних санітарних норм і правил захисту населення від впливу електромагнітних випромінювань № 266 від 13.03.2017” [Електронний ресурс]. - Режим доступу: https://zakon.rada.gov.ua/laws/show/z0625-17.

6. Попов И.И. Анализ состояния нормативной базы по обеспечению электромагнитной безопасности в Украине / И.И. Попов, О.А. Тесленко, Н.И. Тесленко // Системи управління, навігації та зв'язку. - 2015. - № 2(34). - С. $124-131$.

7. Дзюндзюк Б.В. Обеспечение электромагнитной безопасности в местах жилой застройки [Електронний ресурс] / Б.В. Дзюндзюк, И.И. Хондак. - Режим доступу: https://revolution.allbest.ru/life/00966553_0.html.

8. Наказ начальника Генерального штабу Збройних Сил України “Керівництво з медичного забезпечення Збройних Сил України № 317 від 26.12.2013”. - К.: СПД Чалчинська Н.В., 2016. - 511 с.

9. Банный В.А. Оценка уровня электромагнитного фона и способы защиты от СВЧ-излучения / В.А. Банный. - Гомель: ГомГМУ, 2015. - 64 с.

10. Михнюк Т.Ф. Защита от электромагнитных полей радиочастотного диапазона / Т.Ф. Михнюк. - Мн.: БГУИР, 2003. -47 c.

11. Санитарные правила и нормы. СанПиН 2.2.4/2.1.8.055-96. Электромагнитные излучения радиочастотного диапазона [Електронний ресурс]. - М.: Госкомсанэпиднадзора России, 1996. - Режим доступу: http://www.vashdom.ru/sanpin/224_218055-96/.

12. Гигиенические нормативы 2.1.8.11-4-2005. Предельно допустимые уровни плотности потока энергии, создаваемой радиолокационными станциями в прерывистом режиме воздействия на население [Електронний ресурс]. - Минск: МО3 Республики Беларусь, $2005 . \quad$ - Режим доступу: http://www.levonevski.net/pravo/norm2013/num35/d35236.html.

13. Приказ Министра здравоохранения Республики Казахстан “Санитарно-эпидемиологические требования к радиотехническим объектам № 188 от 23.04.2018” [Електронний ресурс]. - Режим доступу: https://online.zakon.kz/Document/?doc_id=37706168.

14. Наказ Міністерства охорони здоров'я України “Про затвердження Державних санітарних норм та правил при роботі з джерелами електромагнітних полів № 476 від 18.12.2002” [Електронний ресурс]. - Режим доступу: https://zakon.rada.gov.ua/laws/show/z0203-03.

15. Методика розрахунку ефективного значення потужності електромагнітного випромінювання оглядових радіолокаційних систем / В.Й. Климченко, О.В. Бєлавін, В.О. Тютюнник, К.А. Тах’ян // Наука і техніка Повітряних Сил Збройних Сил України. - 2020. - № 1(38). - С. 100-106. - Режим доступу: https://doi.org/10.30748/nitps.2020.38.12. 


\section{Відомості про авторів:}

Климченко Василь Йонович

кандидат технічних наук доцент провідний науковий співробітник

Харківського національного університету

Повітряних Сил ім. І. Кожедуба,

Харків, Україна

https://orcid.org/0000-0003-3999-8130

Бєлавін Олексій Вікторович

кандидат технічних наук

начальник відділу

Командування Повітряних Сил

Збройних Сил України,

Вінниця, Україна

https://orcid.org/0000-0003-4217-2786

\section{Тютюнник Владислав Олександрович}

кандидат технічних наук старший науковий співробітник начальник науково-дослідної лабораторії

Харківського національного університету

Повітряних Сил ім. І. Кожедуба,

Харків, Україна

https://orcid.org/0000-0002-7766-3246

Лук'янчиков Андрій Анатолійович

науковий співробітник

Харківського національного університету

Повітряних Сил ім. I. Кожедуба,

Харків, Україна

https://orcid.org/0000-0002-3584-7901
Information about the authors:

Vasyl Klimchenko

Candidate of Technical Sciences Associate Professor

Lead Research

of Ivan Kozhedub Kharkiv

National Air Force University,

Kharkiv, Ukraine

https://orcid.org/0000-0003-3999-8130

\section{Oleksii Bielavin}

Candidate of Technical Sciences

Chief of Department

of Air Force Command of

UA Armed Forces,

Vinnytsia, Ukraine

https://orcid.org/0000-0003-4217-2786

\section{Vladyslav Tiutiunnyk}

Candidate of Technical Sciences Senior Research

Chief of Research Laboratory

of Ivan Kozhedub Kharkiv

National Air Force University,

Kharkiv, Ukraine

https://orcid.org/0000-0002-7766-3246

\author{
Andrii Lukianchykov \\ Research Associate \\ of Ivan Kozhedub Kharkiv \\ National Air Force University, \\ Kharkiv, Ukraine \\ https://orcid.org/0000-0002-3584-7901
}

\section{АНАЛИЗ НОРМАТИВНО-ПРАВОВОЙ БАЗЫ ДЛЯ ПАСПОРТИЗАЦИИ ПОДРАЗДЕЛЕНИЙ РАДИОТЕХНИЧЕСКИХ ВОЙСК}

В.Й. Климченко, А.В. Белавин, В.А. Тютюнник, А.А. Лукьянчиков

Проведен сравнительный анализ мирового опыта определения предельно допустимых уровней электромагнитных полей в радиочастотном диапазоне для разных категорий населения с нормами и правилами по электромагнитной безопасности населения, которые определены действуюшими в Украине нормативными документами. Обнаружен ряд противоречий в существующей нормативно-правовой базе, которые приводят к искажениям в оценивании реально создаваемой радиотехническими подразделениями угрозы населению и окружающей среде. Предложены научно обоснованные нормы предельно допустимых уровней электромагнитных полей, создаваемых радиолокационными средствами радиотехнических войск, для населения и для лии боевых расчетов, которые подвергаются профессиональному облучению.

Ключевые слова: санитарные правила і нормы, электромагнитная безопасность, предельно допустимые уровни электромагнитных полей, обзорные радиолокационные станции.

\section{ANALYSIS OF NORMATIVE-LEGAL FRAMEWORK OF PASSPORTIZATION OF RADAR TROOPS UNITS}

V. Klimchenko, O. Bielavin, V. Tiutiunnyk, A. Lukjanchykov

The comparative analysis of world experience of determination of maximum possible levels of electromagnetic radiation for the different categories of population with norms and rules which are determinate in Ukraine normative-legal documents is conducted. The row of contradictions in an existent normatively-legal framework, which result in distortions in estimation of really created threats by radar troops units for a population and environment is found. Firstly, the parameters of radar troops objects, which are dangers for military personnel and for population, and have to fall under the passportization are undefined. Secondly, the requirements for maximum possible levels of electromagnetic radiation for radars of radar troops in normative documents are undefined. Thirdly, the uncorrectly concordance of native normative documents of electromagnetic safety with european norms of electromagnetic safety have resulted to nonsense: possible levels of electromagnetic radiation for professional personnel are below of possible levels of electromagnetic radiation for population. The method of determination of maximum possible levels of electromagnetic radiation for radars of radar troops is developed. It is shown, that maximum possible levels must be determined not for all class of radars, and for every type of radar, because the maximum possible levels are depending from technical characteristics of radar. Requirements for maximum possible levels of electromagnetic radiation of main beam of antenna pattern for all types of radars of radar troops are grounded. On the basis of the developed method, the scientifically grounded norms of maximum possible levels of electromagnetic radiation, which radiated by radars of radar troops, for population and for professional personnel are offered.

Keywords: electromagnetic safety, maximum possible levels of electromagnetic radiation, sanitary rules and norms, surveillance radars. 